\title{
60S Ribosomal Protein L5
}

National Cancer Institute

\section{Source}

National Cancer Institute. 60S Ribosomal Protein L5. NCI Thesaurus. Code C107654.

$60 S$ ribosomal protein L5 (297 aa, $\sim 34 \mathrm{kDa}$ ) is encoded by the human RPL5 gene. This protein plays a role in both ribosome formation and RNA binding. 